\title{
Analisis Pasang Surut di Perairan Sungai Musi Menggunakan Metode Least Square (Studi Kasus Intake Air Baku Sistem Gandus Kota Palembang)
}

\author{
Agus Saputra ${ }^{1)}$, Taufik Ari Gunawan ${ }^{2)}$ dan Imroatul C Juliana ${ }^{3)}$ \\ 1) Program Studi Magister Teknik Sipil FT UNSRI, Graha Bukit Asam, Jl. Srijaya Negara Bukit Besar Palembang \\ 2,3) Jurusan Teknik Sipil dan Perencanaan FT UNSRI, Jl. Raya Prabumulih - Km32 Indralaya, Ogan Ilir, Sumsel
}

\begin{abstract}
The tides, which affect the water level of the Musi River causes some problems to occur in Palembang City. One of the main problems related to the tides of the Musi River, especially the low tide, is the failure of the raw water intake building of Regional Drinking Water Company (PDAM) Tirta Musi, Palembang City to operate. At a certain time the river water level recedes, the minimum water level entering the intake pump room is lower than the safe level for the pump to run. In this study, an analysis of the tides of the Musi River was carried out using the Least Square method to evaluate the design of the raw water intake building for the Gandus system to disclose whether it meets the minimum elevation requirements for pump operation. The field observations of the tides were carried out for 15 days for every 1 hour to obtain the primary data for this study using the Hobo Water Meter. The results of this study indicate that the type of the tides in the location of the study is a mixed tidal type with a Formzahl Value of 2.01. 4. Against the design plan of the gandus system of raw water intake, there is a chance that the elevation of the river water level is at $0.5 \mathrm{~m}$ from the end of the pump suction pipe, in which the pump cannot function.
\end{abstract}

Key Words: Hobo Water Meter, Least Square, Raw Pump, Tides, Water Intake

\section{PENDAHULUAN}

Kota Palembang adalah salah satu kota di Indonesia dan secara geografis terletak diantara $2^{\circ}$ 52' sampai dengan $3^{\circ} 5^{\prime}$ ' Lintang Selatan dan $104^{\circ}$ 37' sampai dengan $104^{\circ} 52^{\prime}$ Bujur Timur dengan ketinggian topografi rata - rata 8 meter dari permukaan laut. Kota Palembang meiliki luas sebesar 400,61 $\mathrm{km}^{2}$ yang terdiri dari 16 kecamatan dan 107 kelurahan. Kota Palembang berbatasan dengan berbagai wilayah sekitar yaitu di sebelah utara, timur dan barat berbatasan dengan Kabupaten Banyuasin dan sebelah selatan berbatasan dengan Kabupaten Muara Enim. Palembang merupakan kota sungai, ada 4 (empat) sungai besar yang melintasi Kota Palembang yaitu Sungai Musi yang memiliki lebar rata-rata 504 meter, Sungai Komering dengan lebar rata - rata 236 m, Sungai Ogan dengan lebar rata - rata $211 \mathrm{~m}$, serta Sungai Keramasan dengan lebar rata - rata 103 m. Sungai Musi dipengaruhi oleh pasang surut muka air laut yang menyebabkan fluktuasi yang cukup besar terutama saat musim kemarau. Pola aliran sungai di Kota Palembang bisa digolongkan termasuk pada pola aliran dendritik, yaitu seperti sebuah ranting pohon, yang mana aliran Sungai Musi sebagai batang pohon dan sungai kecil lainnya yang bermuara ke Sungai Musi sebagai ranting pohonnya. (Bappeda Kota Palembang, 2013).
Air permukaan Sungai Musi yang dipengaruhi oleh pasang surut (pasut) air laut menyebabkan beberapa permasalahan di Kota Palembang. Salah satu permasalahan yang kerap dihadapi masyarakat Kota Palembang adalah banjir. Tinggi pasang Sungai Musi yang mencapai 0,7 - 2,2 meter yang menyebabkan terjadi aliran balik menuju hulu sungai kecil sejauh 1.100 - 3.500 meter (Belladona, 2005) ditambah pula limpasan air dari hulu akibat intensitas hujan yang tinggi, memperbesar terjadinya resiko banjir di Kota Palembang.

Permasalahan lain yang utama terkait dengan pasang surut Sungai Musi, khususnya kondisi air surut adalah tidak dapat beroperasinya bangunan intake air baku PDAM Tirta Musi Kota Palembang. Beberapa kejadian di intake air baku Sistem Borang, Sistem Ogan 1, Sistem Karang Anyar, pada waktu tertentu kondisi muka air sungai surut, level muka air minimum yang masuk ke ruang pompa intake lebih rendah dari pada level aman pompa bekerja. Hal ini menyebabkan PDAM menghentikan operasi 1-2 jam selama 3-4 hari sehingga tidak dapat melayani 12.699 pelanggan di Kecamatan Plaju, 22.502 pelanggan di Kecamatan Seberang Ulu 1 dan 7.397 pelanggan di Kecamatan Kertapati. (PDAM Tirta Musi, 2015).

Pasang surut merupakan peristiwa fluktuasi muka air laut yang disebabkan oleh adanya gaya tarik benda-benda di langit, terutama matahari dan 
bulan terhadap massa air laut di bumi (Pratama, dkk 2015). Informasi mengenai pasang surut sangat penting agar diketahui elevasi muka air tinggi rata rata / Mean High Water Level (MHWL), elevasi muka air paling surut / Lowest Low Water Level (LLWL), dan elevasi muka air paling tinggi / Highest High Water Level (HHWL) yang bermanfaat untuk menentukan elevasi puncak bangunan pemecah ombak, dermaga pelabuhan, kedalaman alur pelayaran kapal dan bangunan air lainnya (Triatmodjo, 1999 dalam Rosmiati Ahmad dkk, 2017). Pengamatan pasang surut yang paling baik adalah selama 18,6 tahun (Pariwono, 1985 dalam Dahuri dkk, 1996). Sifat pasang surut adalah periodik atau berulang sehingga peristiwa pasang surut dapat diramalkan.

Berdasarkan hal-hal tersebut diatas, salah satu faktor terpenting yang dibutuhkan untuk mengatasi persoalan yang terjadi di Kota Palembang akibat pengaruh pasang surut muka air Sungai Musi, baik itu banjir maupun intake air baku yang tidak dapat beroperasi adalah dengan mengetahui elevasi muka air MHWL, LLWL, dan HHWL. Elevasi - elevasi tersebut akan menjadi referensi dalam kegiatan pembangunan infrastruktur pengendali banjir maupun pembangunan intake air baku PDAM di Kota Palembang. Keakuratan penentuan elevasi elevasi tersebut sangat bergantung pada keakuratan prediksi pasang surut. Demikian pula keakuratan prediksi pasang surut sangat bergantung pada keakuratan perhitungan komponen pasang surut.

Pada tahun 2015, PDAM Tirta Musi Kota Palembang melakukan kegiatan penyusunan perencanaan teknis Detail Engineering Design (DED) Intake dan Pipa Air Baku IPA Sistem Gandus mengambil air dari Sungai Musi tepatnya di Kelurahan Pulokerto Kecamatan Gandus Kota Palembang. Untuk menghindari terjadinya kondisi level air minimum yang masuk ke ruang pompa intake lebih rendah dari pada level air pompa bekerja maka perlu dilakukan analisis pasang surut di lokasi rencana intake. Pada penelitian ini akan dilakukan analisis terhadap pasang surut Sungai Musi menggunakan metode Least Square bertujuan untuk mengevaluasi desain bangunan intake air baku sistem Gandus apakah telah memenuhi kebutuhan elevasi minimal untuk operasi pompa.

\section{Pengertian Pasang Surut}

Pasang surut adalah suatu fluktuasi muka air laut yang diakibatkan oleh adanya gaya tarik-menarik benda-benda astronomi di langit, utamanya matahari dan bulan terhadap massa air laut yang berada di bumi.

Pasang surut timbul akibat adanya gerakan dari benda-benda di angkasa yaitu perputaran (rotasi) bumi pada sumbunya, peredaran (revolusi) bulan mengitari bumi serta peredaran (revolusi) bulan mengitari matahari. Gerakan benda-benda angkasa tersebut akan menyebabkan terjadinya beberapa jenis gaya di tiap lokasi di permukaam bumi, gayagaya tersebut diketahui sebagai gaya utama pembangkit pasang surut muka air laut. Masingmasing gaya akan menimbulkan pengaruh terhadap kejadian pasang surut yang disebut dengan komponen utama konstanta pasang surut dan gaya tersebut merupakan pengaruh matahari maupun bulan atau kombinasi diantara keduanya.

Untuk tiap-tiap benda astronomi yang menyebabkan proses terjadinya peritiwa pasang surut, matahari dan bulan merupakan benda yang paling mempengaruhi dengan 3 (tiga) jenis gerak utama yang menentukan pola pasang surut air laut di bumi. Ketiga gerakan tersebut ialah :

1. Perputaran atau revolusi bulan mengitari bumi, yang orbitnya berbentuk elips serta waktu yang dibutuhkan dalam satu periode putaran selama 29,5 hari;

2. Perputaran atau revolusi bumi mengitari matahari, yang orbitnya berbentuk elips serta waktu yang dibutuhkan dalam satu periode putaran selama 365,25 hari;

3. Perputaran bumi pada porosnya atau rotasi bumi serta waktu yang dibutuhkan dalam satu periode putaran selama 24 jam. Rotasi bumi pada sumbunya ini tidaklah menyebabkan fenomena pasang surut, akan tetapi memberikan pengaruh pada tinggi muka air pasang surut.

Akibat perputaran bumi dan bulan pada lintasan atau orbitnya tersebut, maka posisi bumi - bulan matahari akan selalu berubah-ubah setiap waktu. Pada tanggal 1 (satu) atau bulan baru dan 15 (lima belas) atau bulan purnama tiap bulannya kedudukan anatara bumi - bulan - matahari akan berada pada suatu garis yang lurus, hal ini mengakibatkan gaya tarik-menarik bulan dan matahari terhadap bumi saling menguatkan. Kondisi seperti ini menyebabkan terjadinya pasang purnama / pasang besar (spring tide), yang mana tinggi muka air pasang surut menjadi begitu besar jika dibandingkan dengan hari - hari lainnya. Sedangkan pada sekitaran tanggal 7 (tujuh) atau bulan seperempatd dan tanggal 21 (dua puluh satu) atau bulan tigaperempat tiap bulannya, kedudukan bulan dan matahari membentuk sudut sembilan puluh derajat (siku - siku) terhadap bumi. Hal ini mengakibatkan gaya tarik-menarik bulan dan matahari terhadap bumi saling melemahkan. Kondisi seperti ini menyebabkan terjadinya pasang surut perbani (neap tide) yang mana tinggi muka air pasang surut menjadi begitu sangat kecil bila dibandingkan hari hari lainnya. 

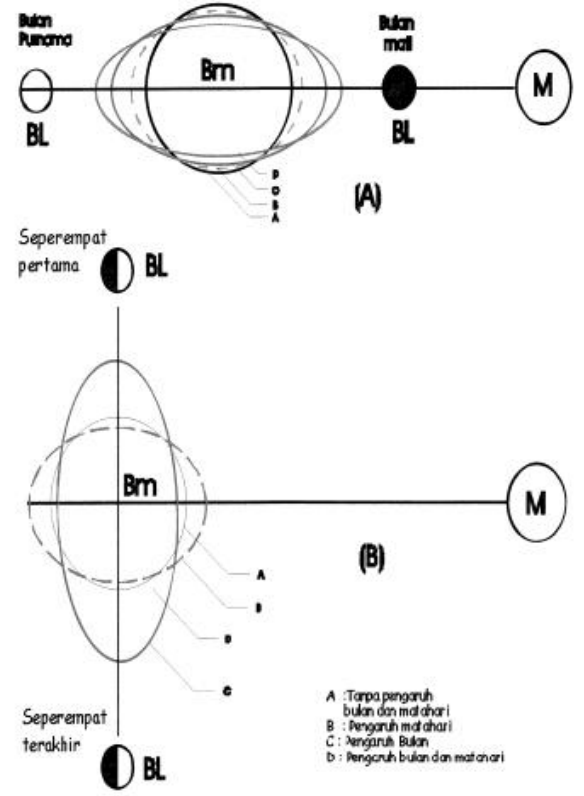

Keterangan :

(A) Posisi Bumi-Bulan - Matahari Saat Pasang Purnama (B) Posisi Bumi-Bulan - Matahari Saat Pasang Perbani Sumber: http://www.operationaloceanographybrokdkp.com/index.php?news $=15$

Gambar 2 Posisi Bumi-Bulan-Matahari Saat Pasang

Perairan laut memberikan respon yang berbeda terhadap gaya pembangkit pasang surut, sehingga terjadi tipe pasut yang berlainan di sepanjang pesisir. Menurut Dronkers (1964), ada tiga tipe pasut yang dapat diketahui, yaitu :

1. Pasang surut diurnal. Yaitu bila dalam sehari terjadi satu satu kali pasang dan satu kali surut. Biasanya terjadi di laut sekitar katulistiwa.

2. Pasang surut semi diurnal. Yaitu bila dalam sehari terjadi dua kali pasang dan dua kali surut yang hampir sama tingginya.

3. Pasang surut campuran. Yaitu gabungan dari tipe 1 dan tipe 2, bila bulan melintasi khatulistiwa (deklinasi kecil), pasutnya bertipe semi diurnal, dan jika deklinasi bulan mendekati maksimum, terbentuk pasut diurnal.

Pada umumnya sifat pasang surut di perairan ditentukan dengan menggunakan rumus Formzahl, yang berbentuk:

$\mathrm{F}=\frac{\left(K_{1}+O_{1}\right)}{\left(M_{2}+S_{2}\right)}$

dimana nilai dari Formzahl adalah :

$\mathrm{F}=0.00-0.25$; untuk pasut bertipe ganda (semi diurnal)

$\mathrm{F}=0.26-1.50$; untuk pasut bertipe campuran dengan tipe ganda yang menonjol (mixed, mainly semi diurnal)
$\mathrm{F}=1.51-3.00$; untuk pasut bertipe campuran dengan tipe tunggal yang menonjol (mixed, mainly diurnal)

$\mathrm{F}>3.00$; untuk pasut bertipe (diurnal)

Dimana,

O1 = unsur pasut tunggal utama yang disebabkan oleh gaya tarik bulan

$\mathrm{K} 1=$ unsur pasut tunggal yang disebabkan oleh gaya tarik matahari

M2 = unsur pasut ganda utama yang disebabkan oleh gaya tarik bulan

S2 = unsur pasut ganda utama yang disebabkan oleh gaya tarik matahari

\section{Perhitungan Komponen Pasang Surut}

Metode Least Square (Least Square Method)

Metode Kuadrat Terkecil (Least Square Linear Regression Method) merupakan metode analisis harmonik pasang surut. Dengan metode ini kita bisa menentukan amplitudo (a) dan fasa (Ø) konstituen pasang surut dari data time series $\mathrm{y}(\mathrm{t})$ (elevasi muka air laut). Dengan diketahuinya amplitudo dan fase untuk setiap komponen pasang surut kita bisa memprediksi pasang surut untuk jangka waktu tertentu, serta menentukan elevasi muka air penting misalnya MSL, LLWL, MHWL, dsb. Persamaan metode Least Square untuk analisis harmonik pasang surut sebagai berikut.

$$
\begin{gathered}
\hat{y}=Z_{o}+\sum_{k=1}^{K} H_{k} \cos \left(\omega_{k} t+F_{k}\right) \\
\hat{y}=Z_{o}+\sum_{k=1}^{K} H_{k}\left\{\left[\left(\cos \omega_{k} t\right)\left(\cos F_{k}\right)\right]\right. \\
\left.+\left[\left(\sin \omega_{k} t\right)\left(\sin F_{k}\right)\right]\right\}
\end{gathered}
$$

dengan,

$A_{k}=H_{k} \cos F_{k}$

$B_{k}=H_{k} \sin F_{k}$

sehingga,

$$
\hat{y}=Z_{o}+\sum_{k=1}^{K}\left(A_{k} \cos \omega_{k} t+B_{k} \sin \omega_{k} t\right)
$$

Penjabaran model pasang surut tersebut, adalah:

$$
\widehat{y}_{l}=Z_{o}+\sum_{k=1}^{K} A_{k} \cos \omega_{k} t_{i}+\sum_{k=1}^{K} B_{k} \sin \omega_{k} t_{i}
$$

dimana,

$\hat{\mathrm{Y}} \quad$ : elevasi muka air hasil perhitungan (model)

Zo : elevasi muka air rata - rata

$\mathrm{Ak}, \mathrm{Bk} \quad$ : koefisien atau konstituen yang dihitung

$\mathrm{K} \quad$ : jumlah konstituen yang dihitung

$\mathrm{k} \quad$ : nomor konstituen

wk : kecepatan sudut (frekuensi) komponen pasut $\mathrm{k}$

: waktu (data)

: waktu ke - i 
Besaran Amplitudo dan Beda Fase masing - masing komponen pasang surut dihitung dengan:

- Phase komponen pasang surut

dimana,

$$
F_{k}=\operatorname{ArcTan} \frac{B_{k}}{A_{k}}
$$

$\mathrm{F}_{\mathrm{k}} \quad$ : Phase komponen pasang surut $\mathrm{k}$

$\mathrm{A}_{\mathrm{k}}, \mathrm{B}_{\mathrm{k}}$ : koefisien atau konstituen yang dihitung $\mathrm{k}$

$\mathrm{k} \quad$ : nomor konstituen

- Amplitudo komponen pasang surut

$$
H_{k}=\sqrt{A_{k}^{2}+B_{k}^{2}}
$$

dimana,

$\mathrm{H}_{\mathrm{k}} \quad$ : Amplitudo komponen pasang surut $\mathrm{k}$

$\mathrm{A}_{\mathrm{k}}, \mathrm{B}_{\mathrm{k}}$ : koefisien atau konstituen yang dihitung $\mathrm{k}$

$\mathrm{k}$ : nomor konstituen

\section{Validasi Prediksi Pasang Surut}

Dengan diketahuinya semua komponen pasang surut, dapat dilakukan perhitungan prediksi pasang surut. Selanjutnya dilakukan validasi hasil perhitungan prediksi pasang surut. Validasi hasil perhitungan prediksi pasang surut dengan data pengamatan pasang surut menggunakan metode Mean Relative Error (MRE).

$$
R M S E=\sqrt{\frac{\sum_{i=1}^{m}\left(a_{o i}-a_{p i}\right)^{2}}{m}}
$$

dimana,

$$
\begin{aligned}
& \mathrm{a}_{\mathrm{oi}} \text { : Data hasil pengamatan / pengukuran ke-i } \\
& \mathrm{a}_{\mathrm{oi}}: \text { Hasil perhitungan prediksi ke-i } \\
& \mathrm{i}: \text { data ke-i } \\
& \mathrm{m} \text { : Jumlah data }
\end{aligned}
$$

\section{Elevasi Muka Air Penting Pasang Surut}

Elevasi muka air penting pasang surut dengan menggunakan nilai Ampitudo, Fase dari komponen pasang surut yang telah didapatkan sebelumnya, diperhitungkan dengan:

- $\mathrm{HHWL}=\mathrm{Z}_{0}+\left(\mathrm{M}_{2}+\mathrm{S}_{2}+\mathrm{K}_{2}+\mathrm{K}_{1}+\mathrm{O}_{1}+\mathrm{P}_{1}\right)$

- $\mathrm{MHWL}=\mathrm{Z}_{0}+\left(\mathrm{M}_{2}+\mathrm{K}_{1}+\mathrm{O}_{1}\right)$

- $\mathrm{MSL}=\mathrm{Z}_{0}$

- $\mathrm{MLWL}=\mathrm{Z}_{0}-\left(\mathrm{M}_{2}+\mathrm{K}_{1}+\mathrm{O}_{1}\right)$

- $\mathrm{CDL}=\mathrm{Z}_{0}-\left(\mathrm{M}_{2}+\mathrm{S}_{2}+\mathrm{K}_{1}+\mathrm{O}_{1}\right)$

- $\mathrm{LLWL}=\mathrm{Z}_{0}-\left(\mathrm{M}_{2}+\mathrm{S}_{2}+\mathrm{K}_{2}+\mathrm{K}_{1}+\mathrm{O}_{1}+\mathrm{P}_{1}\right)$

- $\mathrm{LAT}=\mathrm{Z}_{0}-\left(\mathrm{M}_{2}+\mathrm{S}_{2}+\mathrm{N}_{2}+\mathrm{K}_{2}+\mathrm{K}_{1}+\mathrm{O}_{1}+\mathrm{P}_{1}\right.$

$$
\left.+\mathrm{M}_{4}+\mathrm{MS}_{4}\right)
$$

\section{METODOLOGI PENELITIAN}

Lokasi dari penelitian ini adalah Intake Air Baku Sistem Gandus yang merupakan salah satu intake air baku PDAM Tirta Musi Kota Palembang. Intake Gandus berada di Kecamatan Gandus Kota
Palembang. Intake Gandus ditunjukkan pada Gambar 1.

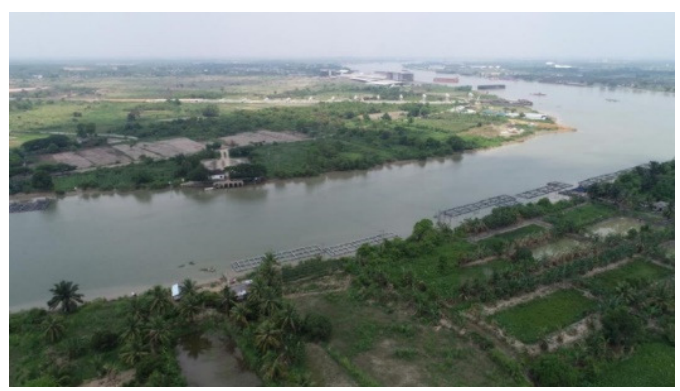

Gambar 1 Lokasi Intake Gandus

Adapun batas-batas penelitian, meliputi:

1) Lokasi penelitian adalah rencana bangunan intake air baku sistem Gandus Kota Palembang yang berada di Sungai Musi.

2) Pengamatan lapangan pasang surut dilakukan selama 15 hari tiap 1 jam untuk mendapatkan data primer.

3) Analisis dan perhitungan komponen serta prediksi pasang surut menggunakan analisa harmonic dengan metode Least Square.

4) Penentuan tipe pasang surut menggunakan persamaan Formzhal.

5) Memvalidasi hasil prediksi pasang surut metode Least Square terhadap data pengamatan lapangan menggunakan metode Mean Roof Square Error (MRSE).

6) Menentukan elevasi penting yang terdiri dari muka air rata - rata / Mean Sea Level (MSL), elevasi muka air paling rendah / Lowest Low Water Level (LLWL), dan elevasi muka air paling tinggi / Highest High Water Level (HHWL) dalam kurun waktu 18,6 tahun.

7) Mengevaluasi elevasi rencana bangunan intake air baku sistem Gandus Kota Palembang berdasarkan elevasi penting pasang surut.

\section{ANALISIS DAN PEMBAHASAN}

Dalam bab ini akan diterangkan mengenai hasil Perhitungan data pasang surut metode Least Square untuk menentukan konstanta harmonik pasang surut air laut diwilayah sekitar intake air baku sistem Gandus PDAM Tirta Musi Kota Palembang dan waktu pengamatannya berdasarkan waktu standar GMT+7 (Greenwich Mean Time) atau dalam waktu lokal WIB (waktu Indonesia bagian barat), serta tanggal pengamatannya dimulai dari tanggal 16 September 2019 sampai dengan tanggal 30 September 2019.

Seluruh data pasang surut ini merupakan hasil dari perekaman data muka air menggunakan Hobo Water Level selama 15 hari (16 September 2019 30 September 2019) yang dipasang di lokasi studi 
kasus yang sudah dilakukan instalasi sebelumnya sebagai berikut:

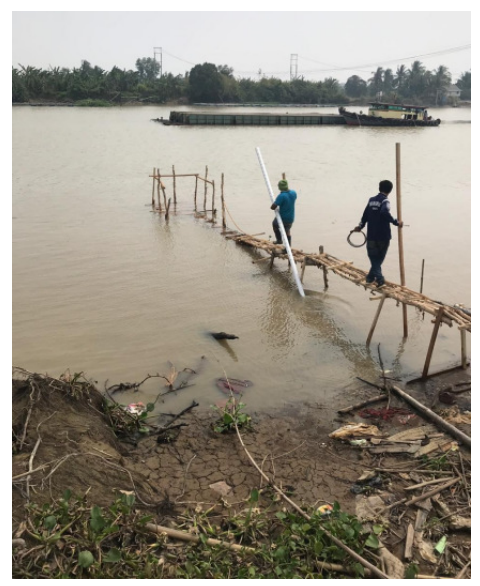

Gambar 3 Lokasi Pemasangan Hobo Water Level di as Rencana Bangunan Intake

Untuk melindungi Hobo Water Level di lapangan dari benturan terhadap benda-benda yang mengalir sepanjang sungai dan juga sebagai penanda peletak maka digunakan pipa PVC yang telah dilubangi. Hobo Water Level lalu dimasukkan kedalam pipa PVC (Gambar 4).
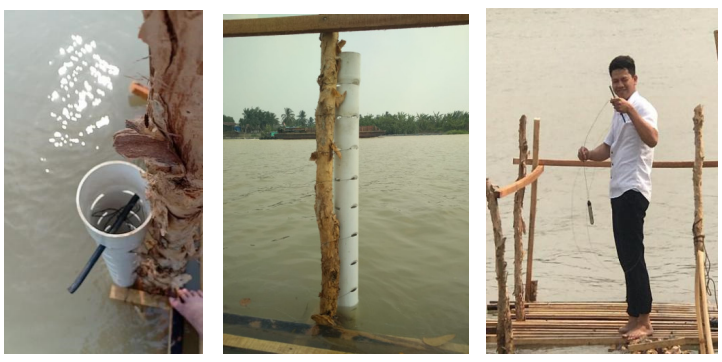

Gambar 4 Pemasangan Hobo Water Level pada Pipa PVC

Setelah 15 hari pengukuran Hobo Water Level lalu diangkat dan disambungkan ke Hoboware untuk membaca hasil pengukuran. Pada Hoboware langsung tampil nilai water level berupa grafik seperti pada Gambar 5.

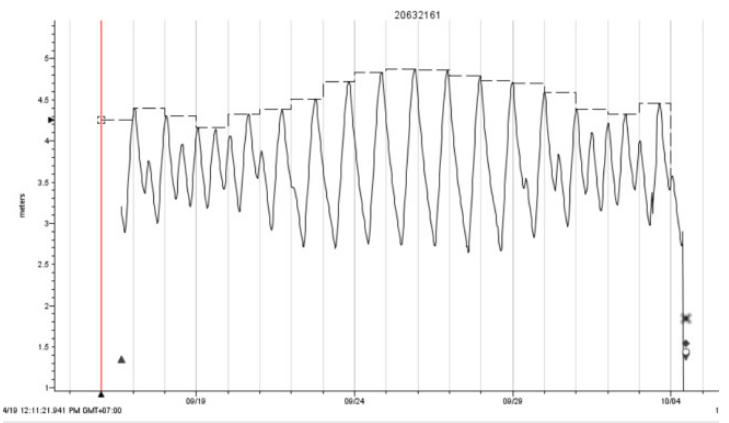

Gambar 5 Grafik Pasang Surut Pada Hoboware
5.1 Analisis Konstanta Harmonik Pasang Surut dengan Metode Least Square

Proses pengolahan data pasang surut ini menggunakan jumlah data selama 15 hari x 24 jam pengamatan pasang surut dan konstanta pengali yang telah ditetapkan, selanjutnya data dan konstanta pengali tersebut akan di analisa dengan perhitungan metode Least Square sehingga menjadi konstanta harmonik pasang surut air laut pada lokasi studi kasus yang telah dilaksanakan.

Dalam studi ini terdapat 360 jam (15 hari x 24 jam) data pengukuran elevasi muka air dan akan ditentukan 9 komponen pasang surut (O1, P1, K1, K2, M2, N2, S2, M4, MS4), maka akan dicari 18 parameter / konstituen (A1, B1, A2, B2, A3, B3, A4, B4, A5, B5, A6, B6, A7, B7, A8, B8, A9, B9) untuk menentukan amplitudo dan fase.

Persamaan Least Square dalam bentuk matriks dapat digambarkan sebagai berikut :

$\left[\begin{array}{c}\widehat{y_{\imath}} \\ \ldots \\ \widehat{y_{360}}\end{array}\right]=\left[\begin{array}{cccccc}1 & \cos \omega_{1} t_{1} & \sin \omega_{1} t_{1} & \ldots \ldots & \cos \omega_{9} t_{1} & \sin \omega_{9} t_{1} \\ 1 & \ldots & \ldots & \ldots \ldots & \ldots & \ldots \\ 1 & \cos \omega_{1} t_{360} & \sin \omega_{1} t_{360} & \ldots \ldots & \cos \omega_{9} t_{360} & \sin \omega_{9} t_{360}\end{array}\right]\left[\begin{array}{c}Z_{0} \\ A_{1} \\ B_{1} \\ \ldots \\ \ldots \\ \ldots \\ A_{9} \\ B_{9}\end{array}\right]$

Disederhanakan

$[\hat{y}]=\left[\begin{array}{c}\widehat{y_{l}} \\ \cdots \\ \widehat{y_{360}}\end{array}\right]$

$[A]=\left[\begin{array}{cccccc}1 & \cos \omega_{1} t_{1} & \sin \omega_{1} t_{1} & \ldots \ldots & \cos \omega_{9} t_{1} & \sin \omega_{9} t_{1} \\ 1 & \ldots & \ldots & \ldots \ldots & \ldots & \ldots \\ 1 & \cos \omega_{1} t_{360} & \sin \omega_{1} t_{360} & \ldots \ldots & \cos \omega_{9} t_{360} & \sin \omega_{9} t_{360}\end{array}\right]$

$[X]=\left[\begin{array}{l}Z_{0} \\ A_{1} \\ B_{1} \\ \cdots \\ \cdots \\ \cdots \\ A_{9} \\ B_{9}\end{array}\right]$

1. Membuat Matriks [y] (360x1), mendefinisikan matrik data hasil pengamatan atau pengukuran 15 hari x 24 jam pengamatan pasang surut, jumlah data 360 jam.

$$
[y]=\left[\begin{array}{c}
y_{1} \\
y_{2} \\
\ldots . . \\
\ldots . . \\
\ldots . . \\
y_{359} \\
y_{360}
\end{array}\right]=\left[\begin{array}{c}
3.93 \\
4.16 \\
\ldots \ldots . . \\
\ldots \ldots . . \\
\ldots \ldots . . \\
3.56 \\
3.84
\end{array}\right]
$$

Tabel 1 Nilai Waktu dan Koefisien y 


\begin{tabular}{|c|c|}
\hline Waktu (Jam) & $\mathbf{y}(\mathbf{m})$ \\
\hline 1 & 3.93 \\
\hline 2 & 4.16 \\
\hline 3 & 4.33 \\
\hline 4 & 4.40 \\
\hline 5 & 4.35 \\
\hline 6 & 4.15 \\
\hline 7 & 3.94 \\
\hline 8 & 3.79 \\
\hline 9 & 3.64 \\
\hline 10 & 3.51 \\
\hline
\end{tabular}$\quad$\begin{tabular}{|c|c|}
\hline Waktu (Jam) & $\mathbf{y}(\mathbf{m})$ \\
\hline 350 & 4.04 \\
\hline 351 & 4.10 \\
\hline 353 & 4.02 \\
\hline 354 & 3.81 \\
\hline 355 & 3.22 \\
\hline 356 & 3.09 \\
\hline 357 & 2.98 \\
\hline 358 & 3.98 \\
\hline 359 & 3.27 \\
\hline 360 & 3.56 \\
\hline
\end{tabular}

2. Membuat Matriks [A] (360x19)

$$
[A]=\left[\begin{array}{cccccc}
1 & \cos \omega_{1} t_{1} & \sin \omega_{1} t_{1} & \ldots \ldots & \cos \omega_{9} t_{1} & \sin \omega_{9} t_{1} \\
1 & \ldots & \ldots & \ldots \ldots & \ldots & \ldots \\
1 & \cos \omega_{1} t_{360} & \sin \omega_{1} t_{360} & \ldots \ldots & \cos \omega_{9} t_{360} & \sin \omega_{9} t_{360}
\end{array}\right]
$$

Sehingga Matriks [A]

$=\left[\begin{array}{cccccc}1 & \cos (0.50587 \times 1) & \sin (0.50587 \times 1) & \ldots \ldots & \cos (1.02947 \times 1) & \sin (1.02947 \times 1) \\ 1 & \ldots & \ldots & \ldots & \ldots \\ 1 & \cos (0.50587 \times 360) & \sin (0.50587 \times 360) & \ldots \ldots & \cos (1.02947 \times 360) & \sin (1.02947 \times 360)\end{array}\right]$

$$
=\left[\begin{array}{cccccc}
1 & 0.8748 & 0.4846 & \ldots . & 0.5153 & 0.8570 \\
1 & \ldots & \ldots & \ldots . & \ldots & \ldots \\
1 & 0.9950 & 0.0997 & \ldots . & 0.9950 & 0.0997
\end{array}\right]
$$

3. Membuat Matrik [X] (19x1),

$$
[X]=\left[A^{T} A\right]^{-1} A^{T}[y]
$$

$[X]=\left[\begin{array}{c}Z_{0} \\ A_{1} \\ B_{1} \\ \ldots \\ \ldots \\ \ldots \\ A_{9} \\ B_{9}\end{array}\right]=\left[\begin{array}{c}3.68262 \\ 0.08500 \\ 0.32291 \\ \ldots \\ \ldots \\ \ldots \\ -0.02323 \\ -0.01656\end{array}\right]$

Koefisien Komponen pasang surut air matrik

$[\mathrm{X}]$ dapat di lihat pada tabel berikut :

Tabel 2 Koefisien Komponen Pasang Surut

\begin{tabular}{lll}
\hline $\mathrm{k}$ & Koefisien & \multicolumn{1}{c}{ Nilai } \\
\hline 1 & Z0 & 3.68262 \\
2 & $\mathrm{~A} 1$ & 0.08500 \\
3 & $\mathrm{~B} 1$ & 0.32291 \\
4 & $\mathrm{~A} 2$ & 0.10466 \\
5 & $\mathrm{~B} 2$ & 0.22537 \\
6 & $\mathrm{~A} 3$ & -0.03759 \\
7 & $\mathrm{~B} 3$ & 0.01522 \\
8 & $\mathrm{~A} 4$ & -0.10262 \\
9 & $\mathrm{~B} 4$ & -0.14996 \\
10 & A5 & 0.65767 \\
11 & $\mathrm{~B} 5$ & 0.17806 \\
12 & A6 & -0.34696 \\
13 & $\mathrm{~B} 6$ & 0.34345 \\
14 & A7 & -0.20855 \\
15 & $\mathrm{~B} 7$ & 0.07782 \\
16 & A8 & -0.00338 \\
17 & B8 & -0.01940 \\
18 & A9 & -0.02323 \\
19 & B9 & -0.01656 \\
\hline
\end{tabular}

\section{Konstanta Harmonik Pasang Surut}

Hasil perhitungan konstanta harmonik pasang

\begin{tabular}{|c|c|c|c|c|c|c|}
\hline \multirow[t]{2}{*}{ No } & \multirow[t]{2}{*}{ Symbol } & \multicolumn{2}{|c|}{ Koefisien } & \multirow{2}{*}{$\begin{array}{c}\text { Amplitudo } \\
\text { (meter) }\end{array}$} & \multirow{2}{*}{$\begin{array}{c}\text { Phase } \\
\text { (der/jam) }\end{array}$} & \multirow{2}{*}{$\begin{array}{c}\text { Phase } \\
\text { (rad/jam) }\end{array}$} \\
\hline & & $\mathbf{A}$ & B & & & \\
\hline 1 & M2 & 0.0850 & 0.3229 & 0.3339 & 75.2529 & 1.3134 \\
\hline 2 & S2 & 0.1047 & 0.2254 & 0.2485 & 65.0899 & 1.1360 \\
\hline 3 & N2 & -0.0376 & 0.0152 & 0.0406 & 157.9562 & 2.7569 \\
\hline 4 & $\mathrm{~K} 2$ & -0.1026 & -0.1500 & 0.1817 & 235.6157 & 4.1123 \\
\hline 5 & $\mathrm{~K} 1$ & 0.6577 & 0.1781 & 0.6813 & 15.1493 & 0.2644 \\
\hline 6 & $\mathrm{O} 1$ & -0.3470 & 0.3435 & 0.4882 & 135.2907 & 2.3613 \\
\hline 7 & P1 & -0.2086 & 0.0778 & 0.2226 & 159.5368 & 2.7844 \\
\hline 8 & M4 & -0.0034 & -0.0194 & 0.0197 & 260.1055 & 4.5397 \\
\hline 9 & MS4 & -0.0232 & -0.0166 & 0.0285 & 215.4769 & 3.7608 \\
\hline
\end{tabular}
surut, adalah sebagai berikut.

Tabel 3 Amplitudo dan Beda Fase

Setelah konstanta harmonik pasang surut telah didapatkan, maka dapat dihitung tinggi pasang surut perhitungan dan digambarkan pada grafik pasang surut pada lokasi studi kasus di rencana bangunan intake air baku sistem Gandus Kota Palembang.

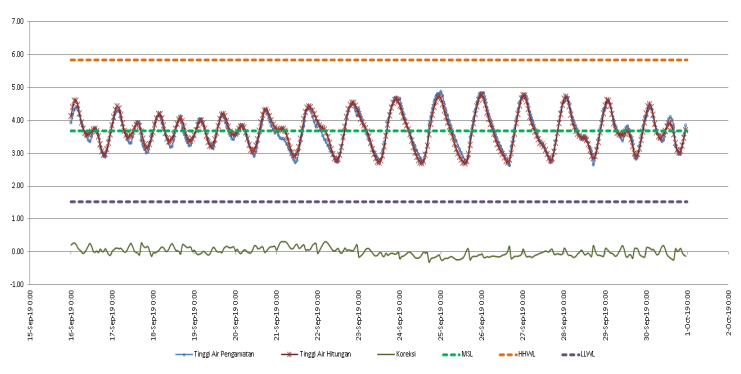

Gambar 6 Grafik Pasang Surut

5.2 Memvalidasi Data Pengamatan Pasang Surut dengan Hasil Prediksi

Selanjutnya dilakukan validasi antara data pengamatan dan hasil perhitungan untuk menilai tingkat kesalahan antara nilai pengamatan dan hasil perhitungan dilakukan dengan metode Mean Relative Error (MRE) dengan MRE sebesar 2,9\% dengan Kebenaran sebesar 97,1\%, sehingga pemodelan dapat digunakan untuk prediksi pasang surut.

\subsection{Menentukan Tipe Pasang Surut}

Berdasarkan perhitungan dengan menggunakan nilai Ampitudo, Fase dari komponen pasang surut yang telah didapatkan sebelumnya maka didapati besaran Nilai Formzahl sebesar 2,01 sehingga tipe pasang surut di lokasi penelitian merupakan tipe Pasang Surut Campuran.

\subsection{Prediksi Pasang Surut selama 18 Tahun 6 Bulan Kedepan}

Prediksi Pasang Surut selama 18 tahun 6 bulan kedepan dari konstanta harmonik pasang surut yang telah diperoleh menggunakan metode Least Square. 
Cantilever | Volume : 9 | Nomor : 2 | Oktober 2020 | ISSN: 1907-4247 (Print) | ISSN: 2477-4863 (Online)|Website: http://cantilever.id Agus Saputra., dkk. I Analisis Pasang Surut di Perairan S.Musi Menggunakan Metode Least Square (St.Kasus Intake Air Baku Sistem Gandus Kota Palembang)

$$
\hat{y}_{i}=Z_{o}+\sum_{k=1}^{K} H_{k} \cos \left(\omega_{k} t_{i}+F_{k}\right)
$$

Hasil prediksi pasang surut selama 18 tahun 6 bulan kedepan dapat dilihat pada grafik berikut ini:

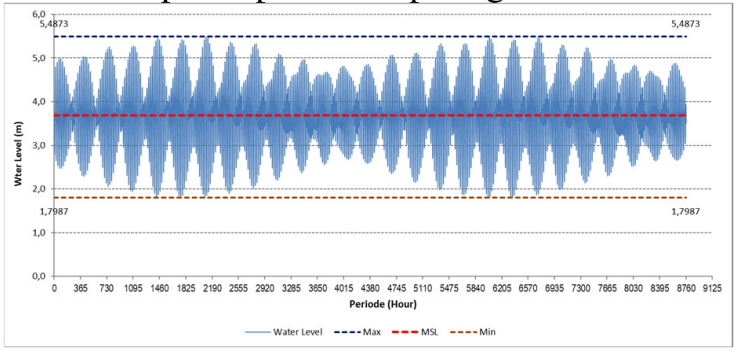

Gambar 7 Grafik Pasang Surut Pada Peramalan Tahun ke- 1

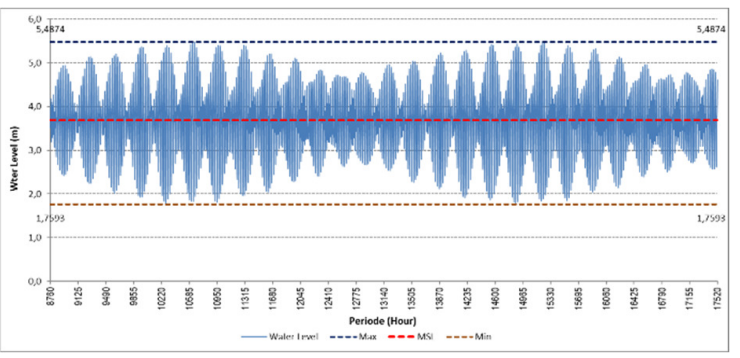

Gambar 8 Grafik Pasang Surut Pada Peramalan Tahun ke- 2

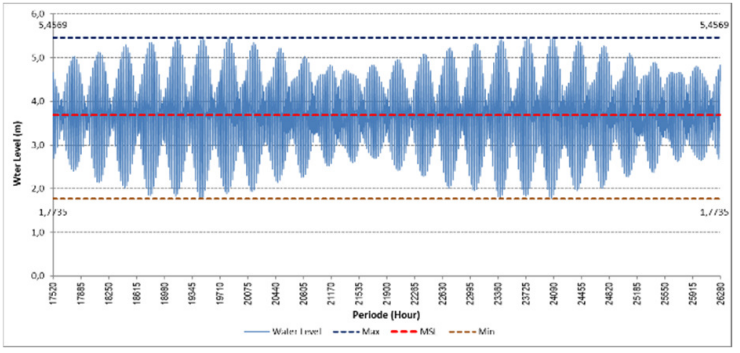

Gambar 9 Grafik Pasang Surut Pada Peramalan Tahun ke- 3

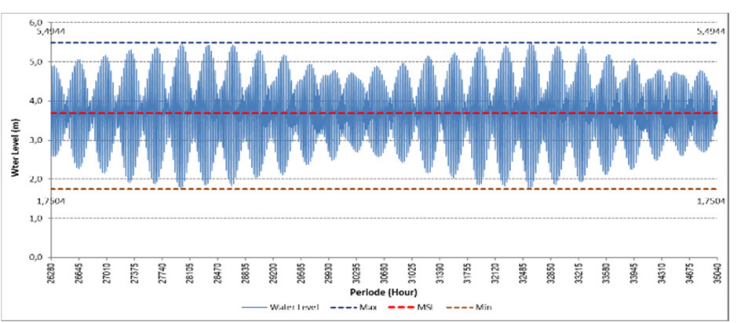

Gambar 10 Grafik Pasang Surut Pada Peramalan Tahun ke- 4
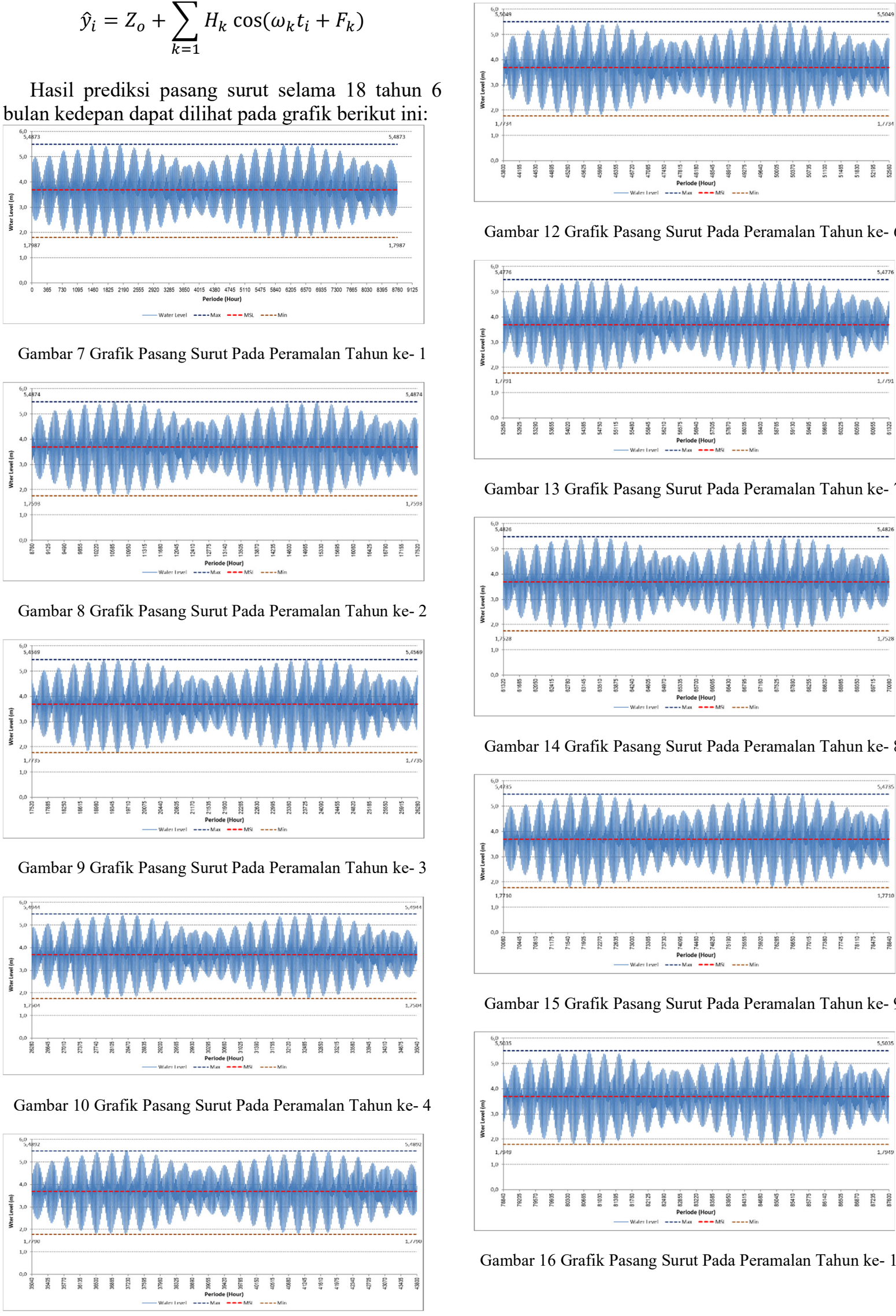

Gambar 12 Grafik Pasang Surut Pada Peramalan Tahun ke- 6

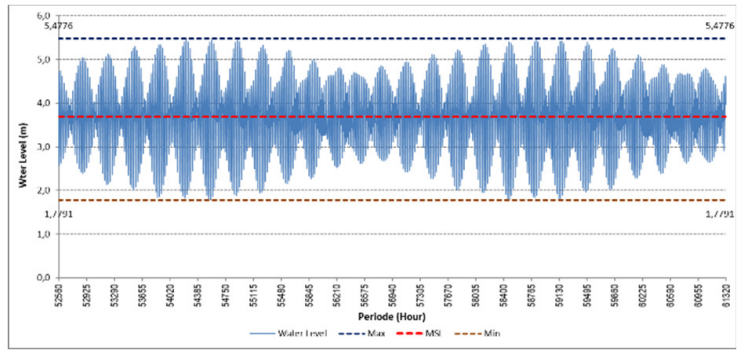

Gambar 13 Grafik Pasang Surut Pada Peramalan Tahun ke- 7

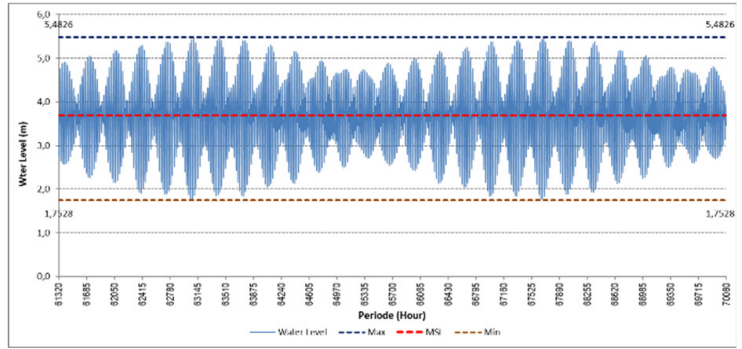

Gambar 14 Grafik Pasang Surut Pada Peramalan Tahun ke- 8

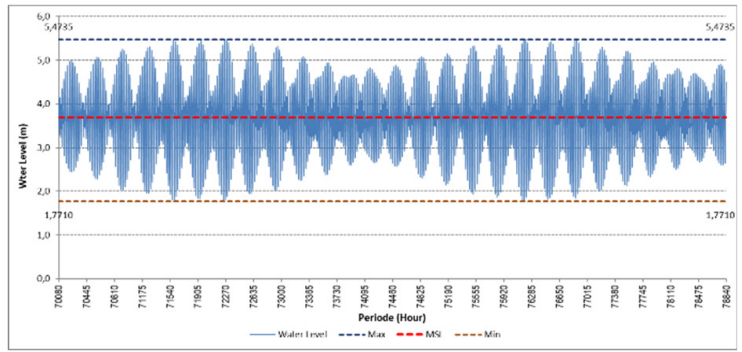

Gambar 15 Grafik Pasang Surut Pada Peramalan Tahun ke- 9

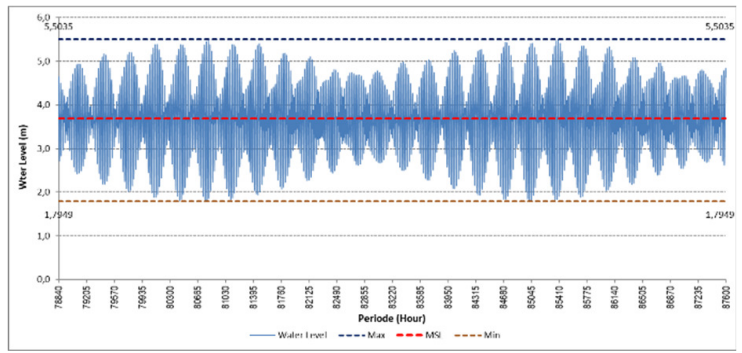

Gambar 16 Grafik Pasang Surut Pada Peramalan Tahun ke- 10

Gambar 11 Grafik Pasang Surut Pada Peramalan Tahun ke- 5 


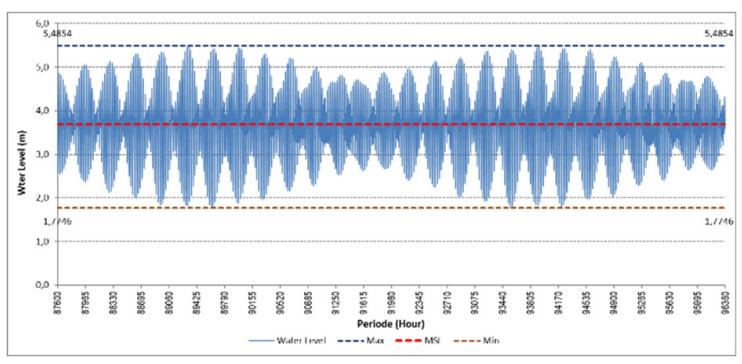

Gambar 17 Grafik Pasang Surut Pada Peramalan Tahun ke- 11

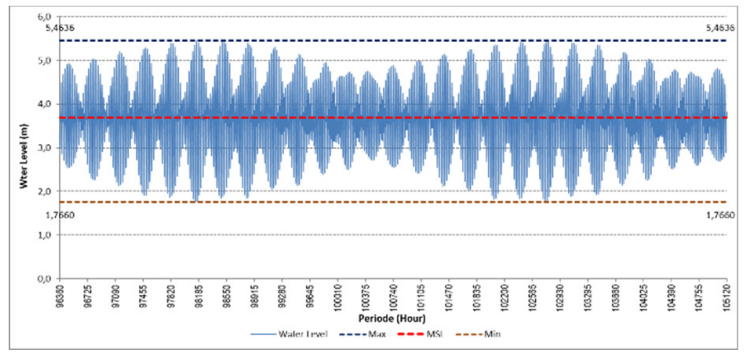

Gambar 18 Grafik Pasang Surut Pada Peramalan Tahun ke- 12

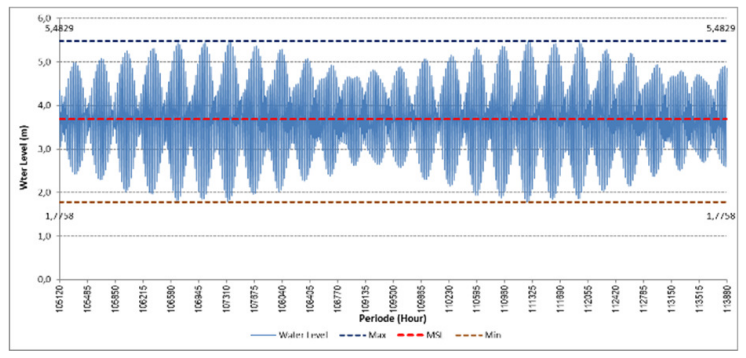

Gambar 19 Grafik Pasang Surut Pada Peramalan Tahun ke- 13

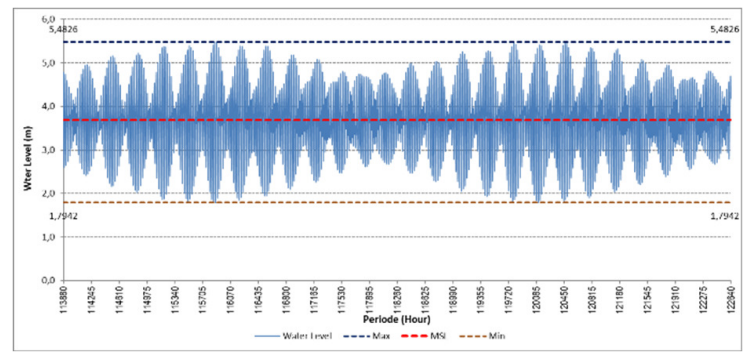

Gambar 20 Grafik Pasang Surut Pada Peramalan Tahun ke- 14

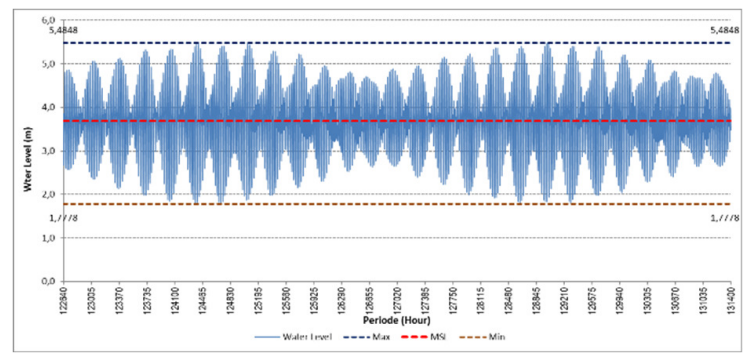

Gambar 21 Grafik Pasang Surut Pada Peramalan Tahun ke- 15

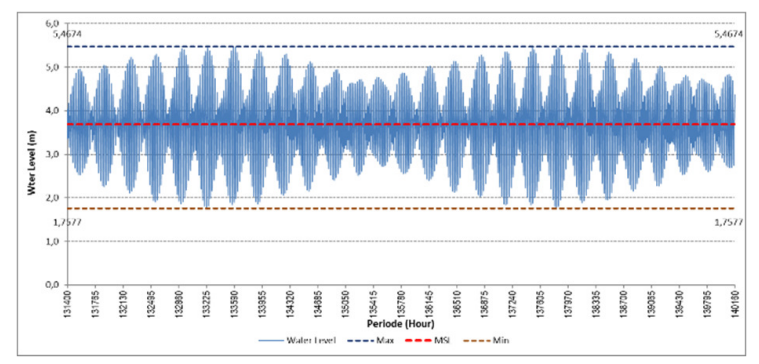

Gambar 22 Grafik Pasang Surut Pada Peramalan Tahun ke- 16

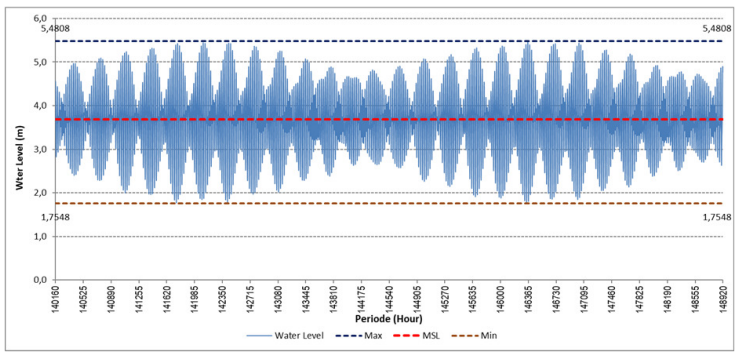

Gambar 23 Grafik Pasang Surut Pada Peramalan Tahun ke- 17

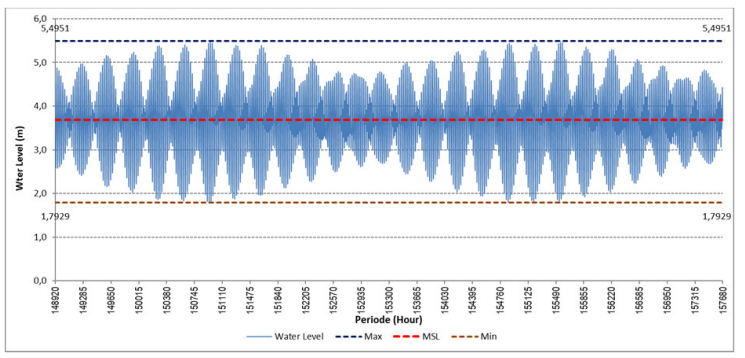

Gambar 24 Grafik Pasang Surut Pada Peramalan Tahun ke- 18

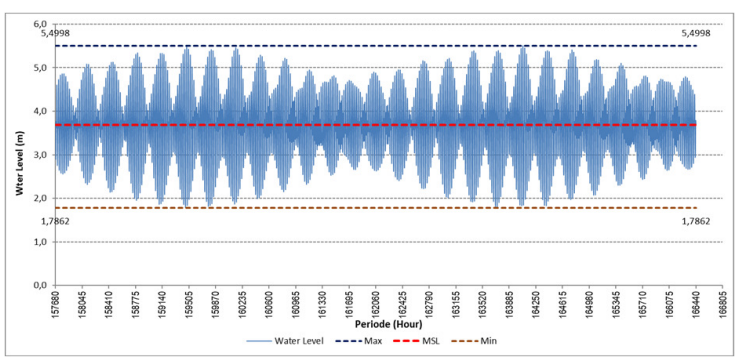

Gambar 25 Grafik Pasang Surut Pd Peramalan Tahun ke- 18,6

5.5 Elevasi Muka Air Penting Pasang Surut

Hasil analisis elevasi penting pasang surut disusun pada Tabel 4.

Tabel 4 Perhitungan Elevasi Penting

\begin{tabular}{|c|c|c|c|c|}
\hline No. & Symbol & \multicolumn{3}{|c|}{ Elevasi (m) } \\
\hline 1 & HHWL & 5.839 & $\approx$ & 5.84 \\
\hline 2 & MHWL & 5.186 & $\approx$ & 5.19 \\
\hline 3 & MSL & 3.683 & $\approx$ & 3.68 \\
\hline 4 & MLWL & 2.179 & $\approx$ & 2.18 \\
\hline 5 & $\mathrm{CDL}$ & 1.931 & $\approx$ & 1.93 \\
\hline 6 & LLWL & 1.526 & $\approx$ & 1.53 \\
\hline 7 & LAT & 1.438 & $\approx$ & 1.44 \\
\hline
\end{tabular}


5.6 Evaluasi Elevasi Muka Air Penting Pasang Surut Terhadap Elevasi Rencana Bangunan Intake Air Baku Sistem Gandus Kota Palembang. Desain rencana bangunan intake air baku Gandus terlihat pada Gambar 26.

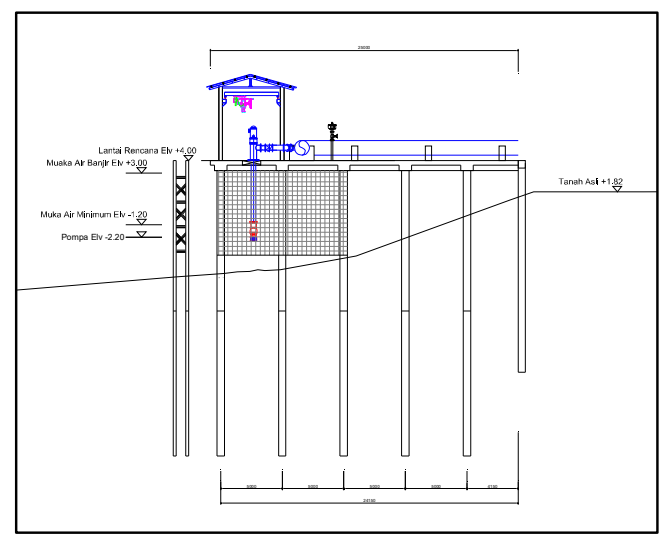

Gambar 26 Penampang Melintang Desain Intake Gandus

Berdasarkan gambar di atas, elevasi lantai intake adalah +4.00 dan elevasi ujung pipa hisap adalah 2.20 , muka air banjir +3.00 dan muka air minimum 1.20 .

Sebelum membandingkan elevasi muka air penting yang diperoleh dari analisis pasang surut terhadap desain rencana bangunan intake, maka perhitungan elevasi penting pada tabel 3 diatas harus diikatkan dengan patok BM (Bench Mark) agar referensi muka air perhitungan sama dengan referensi elevasi dari bangunan intake (Tabel 5).

Tabel 5 Titik ikat BM elevasi penting ke elevasi desain intake

\begin{tabular}{lllll}
\hline No. & Symbol & $\begin{array}{l}\text { Elevasi } \\
(\mathrm{m})\end{array}$ & $\begin{array}{l}\text { Elevasi Alat } \\
\text { Hobo }(\mathrm{m})\end{array}$ & $\begin{array}{l}\text { Elevasi } \\
\text { Konversi }(\mathrm{m})\end{array}$ \\
\hline 1 & HHWL & 5,84 & $-3,24$ & 2,60 \\
2 & MSL & 3,68 & & 0,44 \\
3 & LLWL & 1,53 & & $-1,71$ \\
\hline
\end{tabular}

Elevasi HHWL dan LLWL terhadap elevasi rencana bangunan intake air baku Gandus terlihat pada Gambar 27. Desain bangunan intake air baku sistem Gandus ini menggunakan pompa vertikal turbin dengan spesifikasi pada Gambar 28.

Berdasarkan data tersebut, maka elevasi air sungai di intake air baku sistem gandus tidak memenuhi kriteria elevasi minimal pompa sepanjang tahun. Terdapat peluang kejadian elevasi muka air sungai berada pada $0,5 \mathrm{~m}$ dari ujung pompa sehingga pompa tidak dapat berfungsi

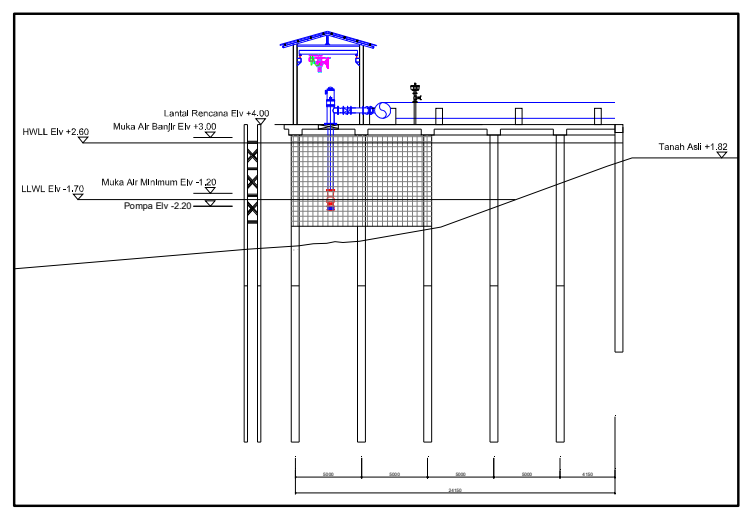

Gambar 27 Elevasi Muka Air Penting Pasang Surut Terhadap Elevasi Rencana Bangunan Intake Air Baku Sistem Gandus Kota Palembang

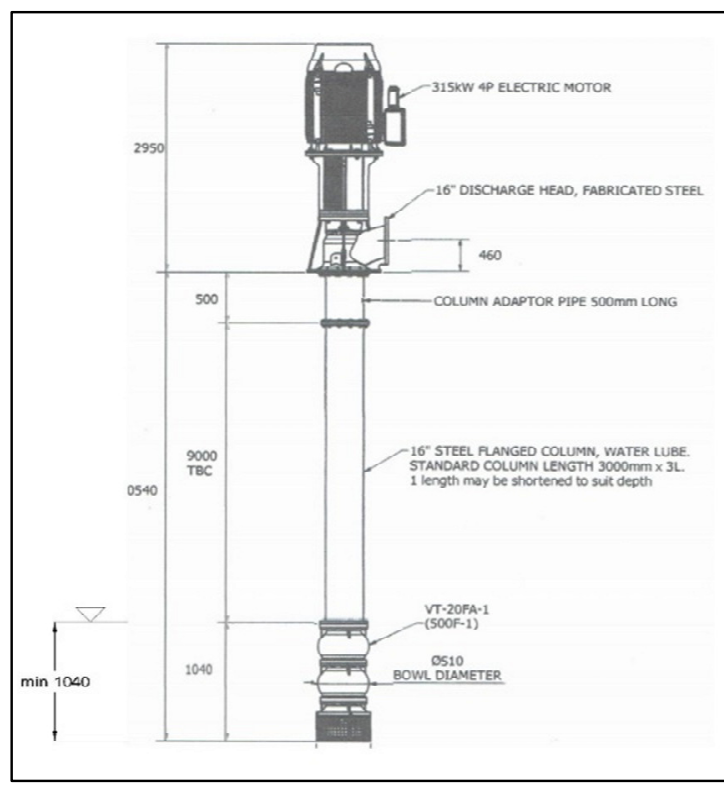

Gambar 28 Spesifikasi pompa rencana

\section{KESIMPULAN}

Berdasarkan hasil penelitian dapat disimpulkan bahwa :

1. Pemodelan prediksi pasang surut dengan menggunakan metode least square memiliki tingkat kesalahan sangat kecil, dengan nilai MRE $=2,9 \%$.

2. Hasil Nilai Formzahl untuk perairan sungai Musi sebesar 2,01, yang berarti tipe pasang surut di lokasi penelitian merupakan tipe pasang surut campuran.

3. Elevasi penting pasang surut dalam kurun waktu 18,6 tahun berdasarkan perhitungan menghasilkan elevasi muka air terendah (LLWL) -1,71 m, elevasi muka air tertinggi (HHWL) $+2,6 \mathrm{~m}$ dan muka air tinggi rerata (MSL) $+0,44 \mathrm{~m}$. 
4. Mengacu pada desain intake air baku sistem Gandus, terdapat peluang kejadian elevasi muka air sungai berada pada $0,5 \mathrm{~m}$ dari ujung pipa isap pompa sehingga pompa tidak dapat berfungsi.

\section{DAFTAR PUSTAKA}

Ahmad, R., Hendri, A., \& Fauzi, M. (2017). Pengaruh Simulasi Awal Data Pengamatan terhadap Efektivitas Prediksi Pasang Surut Metode Admiralty (Studi Kasus Pelabuhan Dumai). Jurnal Online Mahasiswa Fakultas Teknik Universitas Riau, 4, 1-10.

Bappeda Litbang Kota Palembang. (2013). Rencana Pembangunan Jangka Menengah Daerah (RPJMD) Kota Palembang Tahun 2013-2018. Palembang: Bappeda Litbang
Belladona, M. \& Sudibyakto, H.A. (2005). Analisis Factor Lingkungan Penyebab Banjir Kota Palembang. Tesis, Yogyakarta: Universitas Gajah Mada.

Dahuri, R. (1996). Pengelolaan Sumber Daya Pesisir dan Lautan Secara Terpadu. Jakarta: Pradnya Paramita Jakarta.

Dronkers, J. J. (1964). Tidal Theory and Computations. Hydraulic Department of Deltaworks The Hague, Netherlands.

PDAM Tirta Musi. (2015). Penyusunan Perencanaan Teknis (DED) Intake dan Pipa Air Baku IPA Sistem Gandus. Palembang: PT. Multimera Harapan Engineering Consultant.

Pratama, A., Indrayanti, E., dan Handoyo, G. (2015). Peramalan Pasang Surut Di Perairan Pelabuhan Kuala Stabas, Krui, Lampung Barat. Jurnal Oseanografi, 4(2), 508515. 